\title{
Cseres Judit
}

\section{Eltékozolt újszülöttek 2. ${ }^{1}$}

\author{
Wasted newborns 2.
}

\begin{abstract}
Absztrakt
A tanulmány a saját újszülött sérelmére emberölést elkövető anyák helyzetét mutatja be a cselekményhez vezetô utat és okokat kutatva. Módszertani és koncepcionális megközelítésben megismétli a korábbi - 1981-1998 közötti rendőrségi ügyiratok feldolgozása alapján elvégzett - kutatást, áttekinti és elemzi az 1998 és 2018 között ismertté vált esetek ügyészségi ügyirataiból származó adatokat. Az adatok összevetésében a kétszer majd 20 év azonos módon feldolgozott adataiban az időközben lezajlott, a történelminek nevezhető változások hatásait is keresi. Az elkövetők családi helyzetében jelentős változás, hogy hivatalos rangra emelkedett az élettársi kapcsolat. Ebben egyszerre mutatkoznak meg a végleges elköteleződés bizonytalanságai és a kapcsolat önkéntes fenntartásának motívumai. Változott a gyermekvállalás általános életkori képe is. Az első időszakban legtöbben 25 éves korukig, míg a második időszakban a 20-25 éves és a 36-40 éves korukban kerülnek leggyakrabban nem kívánt terhes állapotba. A terhességet a várandósok mindkét időszakban titkolják, azaz veszélyeztetett terhességet hordanak ki. A titok minden áron való fenntartásával magányosan szülnek, és az újszülött létének eltitkolása vezet a halálát okozó végzetes cselekménysorhoz. Tapasztaljuk, hogy az első kutatási szakasz hatására létrejött segítő civil szervezetek jelentősen hozzájárulhatnak az újszülöttölés megelőzéséhez, ezért a további közleményekben a megelőzés további lehetőségei is felmerülnek. Egy következő tanulmány foglalkozik majd az ítélkezési gyakorlat tanulságaival.
\end{abstract}

Kulcsszavak: újszülöttölés, adatok, összefüggések, megelőzés

1 Jelen tanulmány a szerző 2000-ben, a BM Kiadó által megjelentetett „Eltékozolt újszülöttek - Az újszülöttölést elkövetö nök helyzetének kriminológiai elemzése” címü müvének folytatása. 


\begin{abstract}
This article analyses the situation of mothers having committed infanticides of their newborns, looking at the causes along the path that led to the fatal event. Both in terms of concept and methods, the analysis repeats the practice of a predecessor work using official police documents dating to the period between 1981-1998. The present one, however, is based on data extracted from prosecutors offices' files of cases, became known between 1998-2018. In addition to the original ones, the analysis aims at searching for traces of the historic events ensued during these 40 years. A societal change was, that affected also the perpetrators, that cohabitation became a legally recognised alternative to marriage. The increased share of this form of partnership indicates a similar increase both in the uncertainty in final commitments and in voluntary maintenance of relationships. The age pattern of fertility has changed, too. While most of the studied mothers conceive their unwanted pregnancy before the age of 25 in the first period, in the second period, an interesting, new pattern emerges with two "peaks" among the ages of 20-25 and 36-40. Pregnant mothers hide their pregnancy in both periods, so it becomes a high-risk pregnancy. To keep the secret from being discovered as much as possible, they give birth alone. Ultimately, keeping the secret of the newborn leads to the ensuing fatal chain of events. Looking at the second period, one experiences that the NGOs set up to help mothers with unwanted pregnancies can contribute significantly to the prevention of infanticides of newborns. In further articles, we shall explore other means of prevention. A forthcoming article will also explore conclusions drawn from case law of infanticides of newborns.
\end{abstract}

Keywords: neonatal killing, data, correlations, prevention

\title{
Bevezetés
}

„Az újszülött megölése többjelentésü esemény, alig lelhető fel olyan közlemény, amely önálló mozzanatként, s ne tágabb kontextusban tárgyalná. Olyan szimbolikus tettröl van ugyanis szó, amely elsö rátekintésre és mai gondolkodásunk szerint tényszerü megvalósulásában egy nö legbensőbb és legszörnyübb ügye - az itélkezési gyakorlat is ekként kezeli-, pedig jelképezi, tartalmazza a nö egyéni élettörténetét és a nö társadalomtörténetét, valamint a termékenységgel kapcsolatban bármikor és bárhol kialakult szokásokat és a szabályozásukra megfogalmazott normák változását." (Cseres, 2000). Húsz éve, 2000-ben jelent meg az a monográfia, amely a múlt évezred utolsó két évtizedében ismertté 
vált újszülöttölési eseteket szinte teljeskörüen elemzi és az abból idézett fenti gondolat ma is érvényesnek tünik. Legfontosabb megállapításának tekinthető, hogy az újszülöttölés cselekménye - ellentétben az emberölés más eseteivel jó eséllyel megelőzhető. Az elemzés megkísérli követni az újszülött haláláig vezető folyamatot, amelyet a titok és a véletlen útjelzői szegélyeznek. A titok a fogamzástól a szülésig terjedően kíséri, és fennmaradása esetén megpecsételi anya és gyermeke sorsát (Cseres, 1996a). A véletlen, ha képes megtörni a titokkényszer helyzetét és alkalmas kiutat, megoldást kínál, a megelőzés életmentő feladatát teljesíti (Cseres, 1996b). A megvizsgált női élethelyzetekben a titok törvényszerü, a véletlen pedig esetleges, a szakmai és laikus társadalom feladata, hogy segítséget nyújtson a különféle prevenció lehetöségeinek felajánlásával. Az 1990-es években - éppen a 2000-ben közzétett kutatás megállapításai nyomán - a Bölcső Alapítvány és követői azért szerveződtek, hogy erre a sajátos és fenyegető női élethelyzetre adjanak társadalmilag hasznos választ az anya titkának megőrzésével, ám anya és újszülött gyermeke életének megmentésével.

Jelen tanulmányban a két kutatási időszak, azaz a közel kétszer 20 év esetadatainak ismertetésével, összevetésével két, valóban eltérő történelmi időszak sajátságait, hatásait törekszem bemutatni. Az adatokkal egyfelől tapasztalati igazolását adom annak, hogy a titkolt, azaz válságterhesség helyzetében élő várandósok a titok fenntartására törekszenek minden áron, még a szülést követően is. Másfelől pedig - az előző tétellel szoros összefüggésben - arra törekszem, hogy a tapasztalati adatok alapján az elkövető valóságos képét vázoljam fel, amely eltér attól a kegyetlen képtől, amit az ítélkezési gyakorlat alapján a sajtó közvetít a társadalomnak (ez a közvetített kép nem mellékesen hozzájárul a titok mindenáron fenntartásához is). A második kutatási időszak adatait dr. Solt Ágnessel, az Országos Kriminológiai Intézet fömunkatársával tematikus munkamegosztásban dolgoztuk fel (Solt, 2020). Jelen vizsgálat legfőbb módszertani értékét az elöző vizsgálat adataival, megállapításaival összehasonlíthatósága képezi, hiszen

a korábbival nagyjából megegyező időtáv eseteinek az előző vizsgálat módszertani nyomvonalán végig vitt elemzésére nyílt lehetóség. Egyúttal arra tehát, hogy ismét megválaszolhassuk az alapkérdést: ma, azaz az ezredforduló utáni 20 évben ki az a nő, aki - ő legalábbis úgy érzi - kénytelen terhessége titokban tartására, a magányos és végzetes következményekkel járó szülés vállalására?

\section{A felhasznált adatok}

A jelen tanulmány két időszakot különböztet meg: az 1981 és 1997, és az 19982018 közöttit. E két időszak egyben a Cseres (2000) által tárgyalt első, valamint 
az elsőként e cikkben ismertetett második kutatási időszak² 1981 és 2018 között 254 újszülött sérelmére elkövetett emberölés vált ismertté. Az ezekre vonatkozó ügyiratok teljes körét a megyei rendőr-főkapitányságok (1981-1997) és a megyei ügyészségek (1998-2018) bocsátották rendelkezésünkre. Bár az első iratanyag az ismertté vált, a második pedig a jogerős bírói ítélettel zárult esetekre vonatkozik, ugyanazt a (teljes) népességet mutatják. Technikai okok miatt azonban több évre vonatkozóan nincsenek adatok. Az első időszakban ilyen 1995 és 1996, a másodikban pedig 1999, 2000, 2001 és 2002.

Az időszak ügyiratait kétféleképpen dolgoztam fel. Egyrészt lehetőség szerint az esetekre vonatkozó információkat számszerü adatokká kódoltam a szempontok és a jellemzők teljes körének ismertetéséhez (Cseres, 2000) ${ }^{3}$. Másrészt a nehezen vagy nem kódolható, de lényeges információkat hordozó szöveget tematikusan dolgoztam fel, illusztrációként és esetbemutatás céljára használom. Az ismertté vált újszülöttölések évenkénti száma két, egymást követő, lecsengő görbét rajzol ki, közel azonos értékröl, évenként 20 esetről 1982-ben, majd 2000-ben (1. számú ábra). Az idősoron két stabil időszak különíthető el: az 1980-as és a 2010-es évek. Az 1980-as éveket az újszülöttölések nagy, évi átlagosan 17 eset száma, a 2010-es éveket pedig kicsi, évi 2 eset körüli szám jellemezi. A két időszak között nem folyamatos az átmenet. A rendszerváltás körül ez az esetszám erőteljes csökkenésnek indult, és alacsony szinten stabilizálódott (1995-re és 1996-ra nincs adatunk). 2000-ben újra az 1980-as éveket idéző magasságba emelkedik, majd innen csökken le a 2003-2009 közötti évekre jellemző évi átlag 7 esetre (2006 kiemelkedik e sorból). Figyelmet érdemel az utolsó 3 év 0-1-0 esetszáma.

2 Ezeknél a továbbiakban „I. szakasz” és „II. szakasz” megjelölést is alkalmazunk.

3 Ezzel szerzői adatbázist hoztam létre, számításaim és azok grafikus ábrázolása ennek felhasználásával készült. Az I. kutatási időszakban az ügyiratok alapján 197 változót rögzítettem SPSS adatkezelő programban, a II. időszakban is ezek alapján kódoltam adattá az ügyiratok tartalmát. A számításokat és azok grafikai megjelenítését SPSS és Excel programokkal végeztem. Így keletkezett a szerzői adatbázis. 
1. számú ábra: Az újszülött sérelmére elkövetett emberölések ismertté vált esetei 1981 és $2018(+2019)$ között

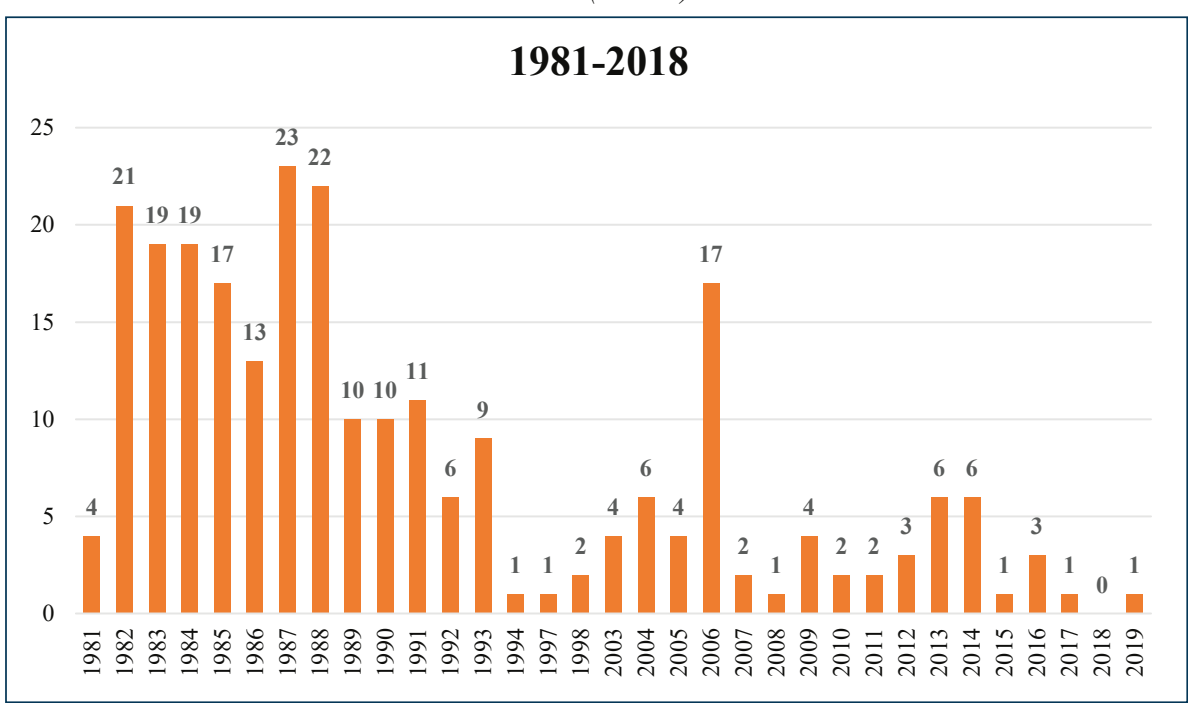

Forrás: ORFK-ENYÜBS.

\section{Az elkövetők lakáskörülményei és demográfiai jellemzői}

Az elkövetök lakáskörülményeit az 1. számú táblázat hasonlítja össze. A két időszakban ismertté vált ügyek területi megoszlásában jelentős változás következett be. A dél-alföldi, de jelentős mértékben a dél-dunántúli esetek aránya is lecsökkent, az észak-magyarországi és az észak-alföldi esetek aránya viszont nagymértékben nőtt az első időszakról a másodikra. Az elkövetők túlnyomó többsége mindkét kutatási szakaszban családi házban vagy saját tulajdonú lakásban élt. A második időszakra mindkettő aránya megnövekedett. Az elkövetők között hajléktalant nem találtam. Fontos mindezek után megtudnunk, hogy az elemzés főszereplője, az elkövető - különösen az adatok összehasonlítása tükrében - milyen minőségben él a lakásban, hiszen ez a kompetenciáját befolyásoló egyik alaptényező. Az elkövetők többsége mindkét kutatási szakaszban (I.: 54,14\%, II.: 65,6\%) családtagként lakott az ingatlanban, tulajdonosi, tulajdonostársi minőségben (I.: 27,5\%, II.: 21,9\%), bérlőként pedig kevesebben (I.: 18,1\%, II.: 15,8\%), jóllehet az albérlet fogalma a két időszakban jelentősen különbözött. Tekintettel a tulajdonlási, illetve a költségvetéshez hozzájárulás következményeire, már itt érdemes utalni arra, hogy a lányok, asszonyok (Cseres, 2000) csoportjának fele (I.: 50\%, II.: 52,9\%) eltartottként élt a lakásban, még 
abban az esetben is, ha GYES-en, GYED-en voltak (I.: 14,7\%, II.: 19\%), és ily módon olykor jelentősen gyarapították a családi költségvetést. A lányok tovább maradtak szülöi családjukban (második kutatási fázis). Tehát eltartották őket, ami a családok többségében kiszolgáltatott helyzetet jelentett. Hasonló helyzetben éltek 1981 és 1997 közötti időszakban a tulajdonosként, de háztartásbeliként otthon élö, többnyire asszonyok.

1. számú táblázat: Az elkövetők lakáskörülményeinek jellemzői az első és a második idöszak összes megfigyelése (185 és 69 eset) százalékában

\begin{tabular}{|c|c|c|c|}
\hline & 1. időszak & 2. időszak & Összesen \\
\hline \multicolumn{4}{|c|}{ Lakás régiója } \\
\hline Budapest & 9,19 & 5,88 & 8,3 \\
\hline Pest megye & 5,95 & 8,82 & 6,72 \\
\hline Közép-Dunántúl & 11,35 & 11,76 & 11,46 \\
\hline Nyugat-Dunántúl & 8,11 & 8,82 & 8,3 \\
\hline Dél-Dunántúl & 17,3 & 10,29 & 15,42 \\
\hline Észak-Magyarország & 17,84 & 26,47 & 20,16 \\
\hline Észak-Alföld & 14,59 & 26,47 & 17,79 \\
\hline Dél-Alföld & 15,68 & 1,47 & 11,86 \\
\hline \multicolumn{4}{|c|}{ Lakás típusa } \\
\hline családi ház & 67,4 & 71,88 & 68,57 \\
\hline öröklakás & 16,57 & 17,19 & 16,73 \\
\hline föbérlet & 6,63 & 3,12 & 5,71 \\
\hline albérlet & 6,63 & 6,25 & 6,53 \\
\hline diák/munkásszállás & 2,76 & 0 & 2,04 \\
\hline szükséglakás & 0 & 1,56 & 0,41 \\
\hline \multicolumn{4}{|c|}{ Háztartásméret (fö) } \\
\hline 2 & 9,73 & 5,88 & 8,7 \\
\hline 3 & 16,22 & 10,29 & 14,62 \\
\hline 4 & 29,19 & 19,12 & 26,48 \\
\hline 5 & 14,59 & 17,65 & 15,42 \\
\hline 6 & 12,97 & 16,18 & 13,83 \\
\hline 7 & 17,3 & 30,88 & 20,95 \\
\hline \multicolumn{4}{|c|}{ Tartózkodás minősége } \\
\hline családtag & 54,14 & 65,62 & 57,14 \\
\hline bérlőtárs & 4,42 & 3,12 & 4,08 \\
\hline főbérlő & 1,66 & 0 & 1,22 \\
\hline albérlő & 12,15 & 9,38 & 11,43 \\
\hline tulajdonos & 27,62 & 18,75 & 25,31 \\
\hline
\end{tabular}

Forrás: A szerző saját, az ügyiratok feldolgozása alapján összeállított adatbázisa

Az első kutatási fázisban a 3-5 fös háztartásméreteket láttam általánosnak. A második kutatási szakaszban a 4-6 fös háztartások aránya a leggyakoribb, de 
összességében kisebb aránnyal. Jelentősen megnövekedett viszont a 6+ fös háztartásméretek, ezzel a népesebb közvetlen társas térben együtt élők aránya. Az elkövetők életkorának megoszlása jellegzetesen eltér a két időszakban (2. számú ábra). Az első időszakban leggyakoribb a 16-17 éves életkor, ez a második időszakra kitolódik és kiszélesedik 18-24 év közé. Megfigyelhető ugyanakkor egy második leggyakoribb életkor, a 36 év körülieké.

2. számú ábra: Az elkövetök életkorának megoszlása a két szakaszban

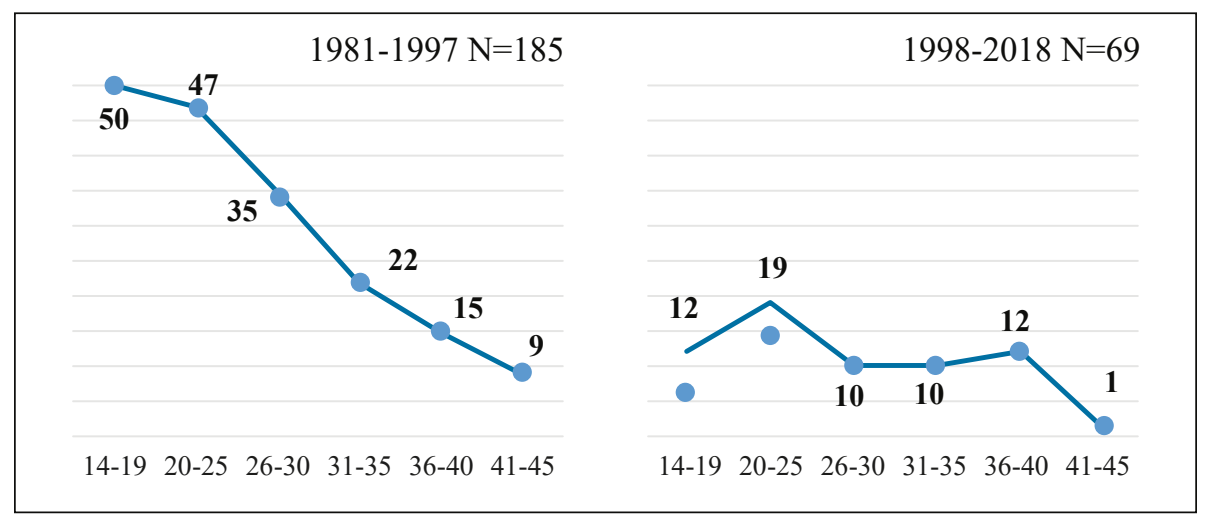

Forrás: A szerző saját szerkesztése.

A kutatás során adatokat gyüjtöttem az elkövetök demográfiai és családi helyzetéröl is (3. számú ábra).

3. számú ábra: Az elkövetők családi állapota

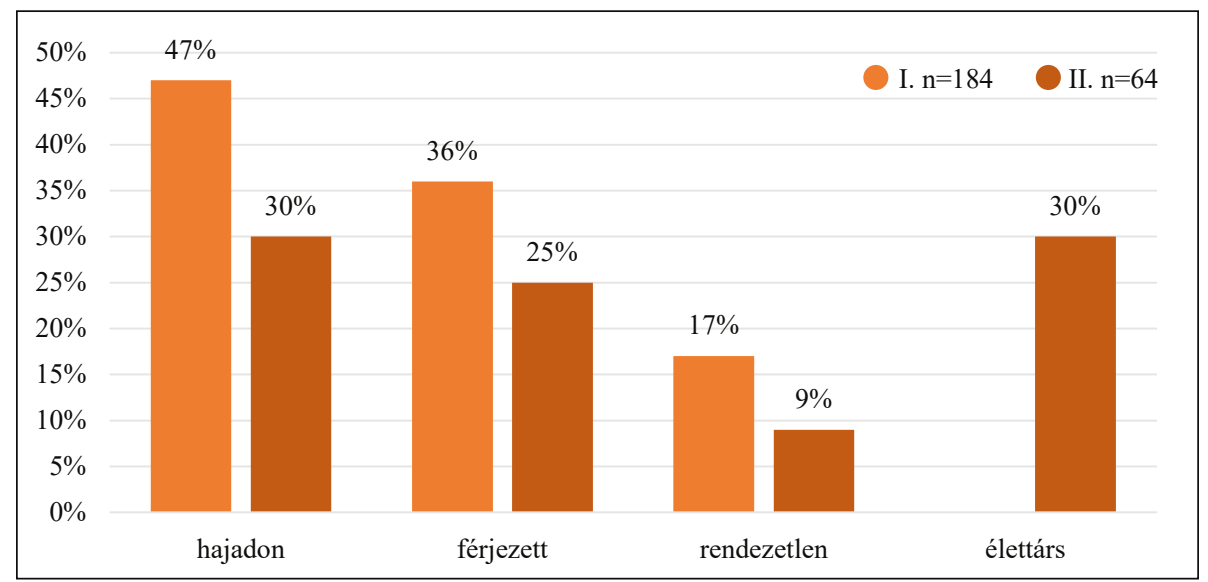

Forrás: A szerző saját szerkesztése. 
A második kutatási szakaszban jelentősen megváltoztak a családi együttélés formái: $36 \%$ helyett az elkövetőknek már csak $25 \%$-a férjezett, hivatalos rangra emelkedett az élettársi kapcsolat, 30\%-os részesedési aránnyal. Az elkövetők többsége 2-4 gyermeket nevel, a családi és intézményes környezet nyilatkozataiból kitünően többnyire gondos, olykor áldozatos anyaként. Az asszonyok 5\%-a és a rendezetlen helyzetüek 20\%-a nem maga neveli gyermekeit. Az esetek teljes elemzéséből kiderül, hogy a gyermekek száma és anyjukkal együttélésének kérdése sokkal bonyolultabb és mozgalmasabb annál, mint amit a lényegében pillanatfelvétel-adataink rögzítenek. Az elkövetők közül többen korábbi kalandjukból, élettársi kapcsolatukból, házasságukból származó gyermekeikkel nem minden esetben élnek együtt.

2. számú táblázat: Az elkövetők demográfiai jellemzői,

az elsö és a második idöszak összes megfigyelése (185 és 69 eset) százalékában

\begin{tabular}{|c|c|c|c|}
\hline & 1. időszak & 2. idöszak & Összesen \\
\hline \multicolumn{5}{|c|}{ Gyermekek száma } \\
\hline 1 & 43,24 & 0 & 31,62 \\
\hline 2 & 14,05 & 13,24 & 13,83 \\
\hline 3 & 17,84 & 25 & 19,76 \\
\hline 4 & 11,89 & 10,29 & 11,46 \\
\hline 5 & 8,11 & 10,29 & 8,7 \\
\hline adathiány & 4,32 & 8,82 & 5,53 \\
\hline \multicolumn{5}{|c|}{ Iskolai végzettség } \\
\hline kisegítö iskola & 3,91 & 32,35 & 9,09 \\
\hline 8 osztálynál kevesebb & 8,94 & 9,52 & 5,37 \\
\hline 8 osztály & 48,6 & 0 & 6,61 \\
\hline szakmunkásképzö & 23,46 & 30,16 & 43,8 \\
\hline szakközépiskola & 6,7 & 38,1 & 27,27 \\
\hline gimnázium & 8,38 & 9,52 & 7,44 \\
\hline \multicolumn{5}{|c|}{ Gazdasági aktivitás } \\
\hline eltartott & 34,83 & 3,17 & 7,02 \\
\hline aktív dolgozó & 48,88 & 35,48 & 34,58 \\
\hline gyesen vagy gyeden & 15,17 & 29,03 & 45,42 \\
\hline betegállomány & 1,12 & 0 & 18,75 \\
\hline
\end{tabular}

Forrás: A szerző saját, az ügyiratok feldolgozása alapján összeállított adatbázisa.

Az elkövetők iskolázottsági összeképe valamelyest módosult. Jelentősen csökkent a legfeljebb 8 osztályt végzettek aránya, hasonló mértékben gyarapodott a 
szakmunkásképzőt elvégzetteké és kissé a szakközépiskolásoké. Valamelyest csökkent az érettségizettek aránya, de az összképhez tartozik, hogy több tizenéves leány (és a gyermek apja is) éppen a cselekmény miatt hagyja abba vagy függeszti fel tanulmányait. A második szakaszban megjelent az OKJ-s képzésben részt vettek $8 \%$-os aránya. Mindkét szakaszban hiányoznak a diplomások. Ahogyan az iskolázottság képe a célratörő és összpontosított szakmai képzés irányába mutat ekkor még enyhe átrendeződéssel, úgy a foglalkozások szerkezete is ezt mintegy követni látszik. Minimálisra csökkent a csak a háztartásban tevékenykedő nők száma, gyarapodott a vállalkozók száma, mutatóba megjelent a közmunkás és a föállású anya foglalkozás. Elenyésző, ám lényeges tapasztalat szerint mindkét időszakban elkövetővé váltak olyan lányok, asszonyok, akik egészségügyi vagy pedagógiai képzettséggel rendelkeztek (13-an), illetve pedagógiai vagy egészségügyi intézményben vállaltak munkát (20fö).

Márta 43 éves, községben, fürdőszoba nélküli 100nm-es családi házban nagykorú fiával él, elvált. Korábban szülészeten dolgozott ápolónőként. A pályát családi gondok és az italozás miatt hagyta el. Azóta alkalmi munkából él napszámosként. Terhességét szégyellte a kora miatt és két felnőtt fia előtt, nem gondolkodott arról, mi lesz a születendő gyermekkel.

Ez a tény zavarba ejtő, hiszen a cselekmény elbírálásakor többnyire súlyosító körülményként veszik tekintetbe. Az ügyiratok tanúsága szerint a titokhelyzet fenntartásának kényszerítő ereje minden más tényezőt felülír, a magányosan szülő nő tudatát erre összpontosítva, beszükítve. A szülés minden tekintetben hasonlóan zajlik, mint a szakismeretekkel nem rendelkezőknél, esetenként csupán a köldökzsinór szakszerübb elvágásában nyilvánul meg. A gazdasági aktivitás arányaiban határozott eltolódás mutatkozik a GYES-en vagy GYED-en levők irányába. Ezzel szinte azonos az aktív dolgozók arányának csökkenése, míg az eltartottaké lényegében változatlan.

\section{Az elkövetők személyes jellemzői}

A család rendezetlen belső konfliktusaira utal, ha a gyermek apja nem a hivatalos pár és nem is élnek együtt (4. számú ábra). 


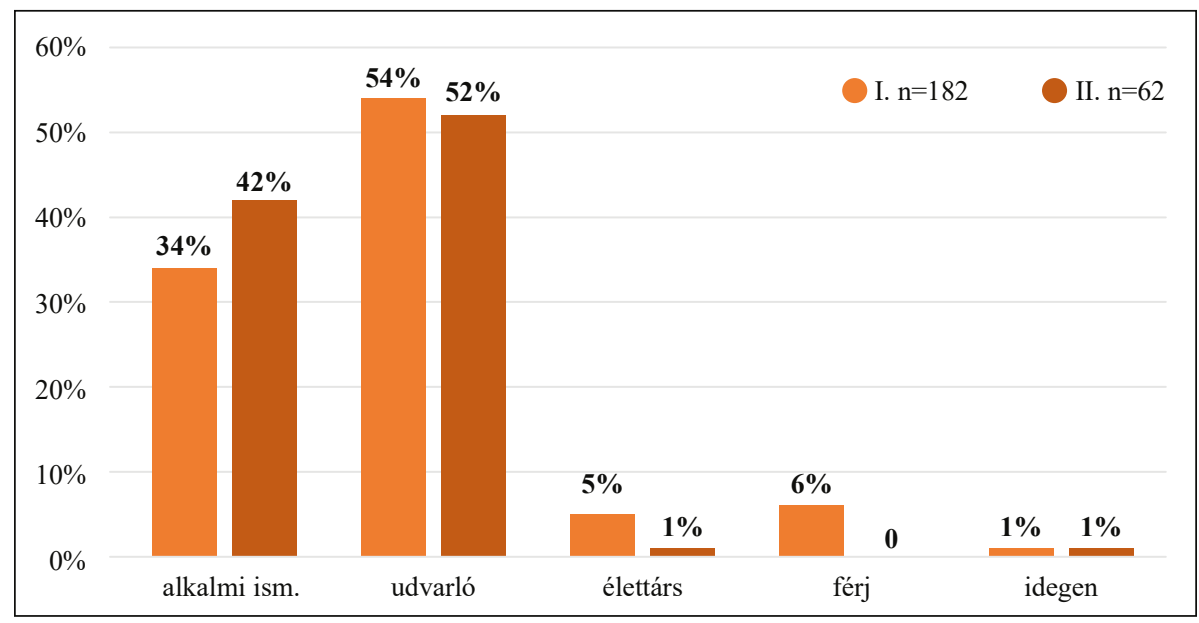

Forrás: A szerző saját szerkesztése.

\section{Alkoholfogyasztás}

Az alkoholfogyasztás lényeges jelzés a társas-társadalmi kapcsolatok fenntartásáról, az idő strukturálásáról, a szorongások oldásáról, a gondok megoldásának halogatásáról. Az elkövetők és közvetlen társas környezetük többsége alkalmanként fogyaszt alkoholt, a születésnapi koccintás, a vasárnapi ebédhez járó ital és más hasonló események szokásos velejárójaként. Úgy ítéltem meg, hogy mindez még a „kulturált alkoholfogyasztás” körébe sorolható, hiszen még azok körében sem alakított ki függőséget, akik például kocsmában vagy borgazdaságban dolgoztak. Más a helyzet azonban a rendszeres alkoholfogyasztókkal, az elkövetők szocializációjában meghatározó szerepet játszó szülők és közvetlen családtagok gyakori részegségével, illetve az elkövető és párja, partnere alkoholizálásával. A kutatás mindkét szakaszában találtam rendszeresen italozó elkövetőt, arányuk 10\% körüli, közülük néhányan ténylegesen alkoholbetegek. Mónika 27 éves, községben, családi házban élnek, férjezett, 5 gyermekük van. Szembe szomszéd: Móniék két éve költöztek ide, a múlt nyáron ismerkedtünk meg közelebbről. Móni ragaszkodott hozzám, főként a régi családi életéről beszélt sokat, amikor otthon lakott a szüleinél. Ezen kívül volt egy kis csókolózás, több nem történt. Október elején átjött Zoli: képzeljétek, megszült a feleségem, de a pulya sehol. Azóta már találkoztunk, mintha nem történt volna semmi. Móni nagyon iszik, általában 1 liter pálinkát megivott egy este. Mi nem fizettünk, akkor volt neki pénze, amikor megkapta a családi pótlékot. 
Családgondozó: családlátogatáskor rendetlenség, a gyerekek félénkek, bejelentés arról, hogy esténként szórakozóhelyre megy, leittasodik, a gyerekeket magukra hagyja, esetkonferencia tervezve.

Az elkövető gyermekének apja azonban már 20\%-os arányban tekinthető rendszeres alkoholfogyasztónak, ez iránt a társadalmi környezet lényegesen elfogadóbb, hiszen a férfiember csak „,megissza a magáét”. Az ügyiratok azonban nemcsak az együtt élő társ alkoholfogyasztási túlkapásairól - a jelenidőben élt élet minőségét meghatározó szerepéről - vallanak, hanem olykor az apák és anyák italozásáról is jelzéseket adnak.

Timi 37 éves. Közepesen súlyos értelmi fogyatékos, a kisegítő 8 osztályt végezte el, nincs szakképzettsége, eleinte alkalmi fizikai munkát vállalt, de már évek óta otthon tartózkodik. 20 éve élettársi kapcsolatban él, 6 gyermekük született, a gyermekek nem velük élnek. Élettársa is, ő is rendszeresen italoznak.

Védőnő: mások gyanakodtak, szóltak nekem, azért jártam ki. Értelmi képességeivel mindig baj volt, az alkohol csak rontott rajta. Szörnyü lakáskörülmények között élnek.

\section{Öngyilkosság}

Az öngyilkosság vagy még inkább az öngyilkossági kísérlet ebben az esetkörben a konfliktusmegoldó kompetencia életbe vágó hiányára vagy legalábbis súlyos torzulására mutat. A cselekményt megelőző időszakban a később elkövetővé vált lányok, asszonyok gyakrabban jelzik megoldhatatlannak érzett konfliktushelyzetüket öngyilkossági kísérlettel (az I. szakaszban 14-en, a II. szakaszban 7-en). A második kutatási fázisban csökkenni látszik az öngyilkossági kísérlet problémamegoldást helyettesítő szerepe. A cselekmény után az I. szakaszban 2 fö, a II. szakaszban 1 fö kísérelt meg öngyilkosságot, aki valóban meg akart halni.

\section{Testalkat}

Az elkövetők többsége mindkét időszakban - többek által megítélve -átlagos testalkatú (59\%), kevesebben kövérek (33\%) és soványak (8\%) $(\mathrm{N}=235)$. A szükebb és tágabb környezet vallomástevői a testalkat változatlanságával magyarázzák tétlenségüket, beavatkozásuk elmaradását. Csupán a senkit nem érdeklő, úgyszólván számkivetetten élők esetében nem kelt figyelmet a terhességre jellemző domborulat látványos fejlődése. Ezzel ellentétes fejlemények is előfordulnak, nem is egy esetben a terhesség időszakában fogyás, súlycsökkenés következik be. 
Tímea 27 éves, 8 általánost végzett, mosogató, a férj tulajdonában lévő lakótelepi lakásban 4-en élnek. T. korábbi kapcsolatából nagylánya a nagyszülőknél él, a kislány velük + egy közös gyerek.

Férj: Az elmúlt hónapokban semmi különöset nem vettem észre, nem voltak rosszullétei, cigizett, ugyanúgy eljárt dolgozni napi 12 órában. Az utóbbi időben kicsit meghízott, mondtam neki, hogy úszógumija van, ezen csak nevetett. Feszes csípőnadrágot hordott övvel. Már 3 éve nincs köztünk intim kapcsolat, csak a gyerekek tartanak össze. A feleségem gyakorlatilag folyamatosan megcsalt. Tudok arról, hogy kb. 2 éve szült egy gyereket és a kórházban hagyta, lemondtunk róla.

\section{5. számú ábra: Az elkövetők értelmi állapota}

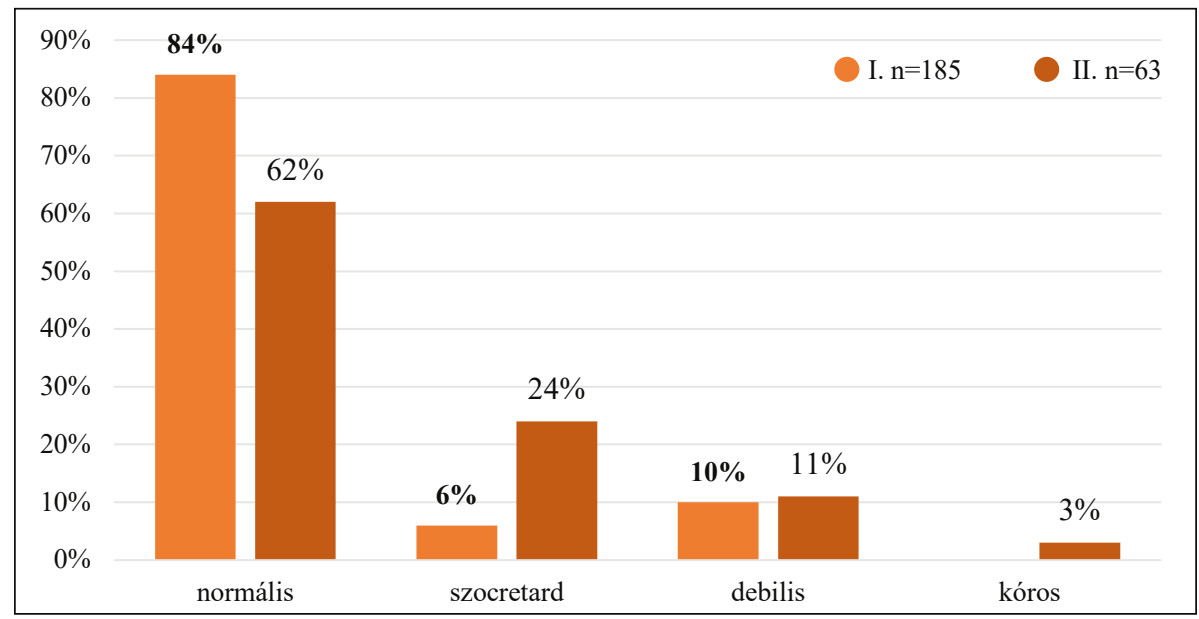

Forrás: A szerző saját szerkesztése.

Az elkövetők értelmi állapotáról (5. számú ábra) a környezet, az iskola, a védőnő egybehangzó véleménye alapján állapíthattam meg, hogy többségüket normálisnak tekintik. A második időszakra jelentősen csökkent a szociálisan retardáltak aránya, s lényegében változatlan a fogyatékkal élők aránya ${ }^{4}$. Az első időszakban a hatósági szakorvosi vélemény az elkövetők 80\%-a esetében állapított meg beszámíthatóságot, a második szakaszban ez 87\%-ra emelkedett,

4 Süle Ferenc pszichiáter a 70-es években saját terápiás gyakorlatában igazolta feltételezését, mely szerint az intézményekben gondozott fogyatékosok örömszerzése az általa alkalmazott aktivitás-programmal elmozdítható az étkezés-alkoholfogyasztás-szexualitás állapotkonzerváló szintjéről az önálló önkiszolgáló és szabadidős tevékenység örömforrásai irányába. Tudomásom szerint eredményeit nem publikálta, szakemberek továbbképzésében ismertette. 
1 esetben állapított meg beszámítási képtelenséget, 10 esetben pedig a beszámítási képesség korlátozottságát ${ }^{5}$. Az ügyiratokban megismert ítéletek azt mutatják, hogy az elkövetőket szabadságvesztés büntetéssel sújtják, kevéssé merül fel - még az első büntényes és gyermekeiket példásan ellátó-nevelő elkövetők esetében sem - a büntetés valamiféle hatékony alternatívája.

\section{A nemi élet sajátságai}

Az elkövetők nemi életének szokásaiban, indítékaiban (6. számú ábra) a hajadonok esetében mindkét kutatási szakaszban hasonlóságot találunk, többen a kapcsolatkeresés időszakában bocsátkoztak alkalmi kalandokba. A házasságban élő asszonyok esetében látszik csüggesztő tendencia, a korábban gyakoribb nemi élet a későbbi szakaszban átadja helyét a rendszertelen házastársi együttléteknek, míg az élettársi kapcsolatokban szeretkeznek leggyakrabban rendszeresen.

6. számú ábra: A fogamzáshoz vezető nemi aktus inditéka

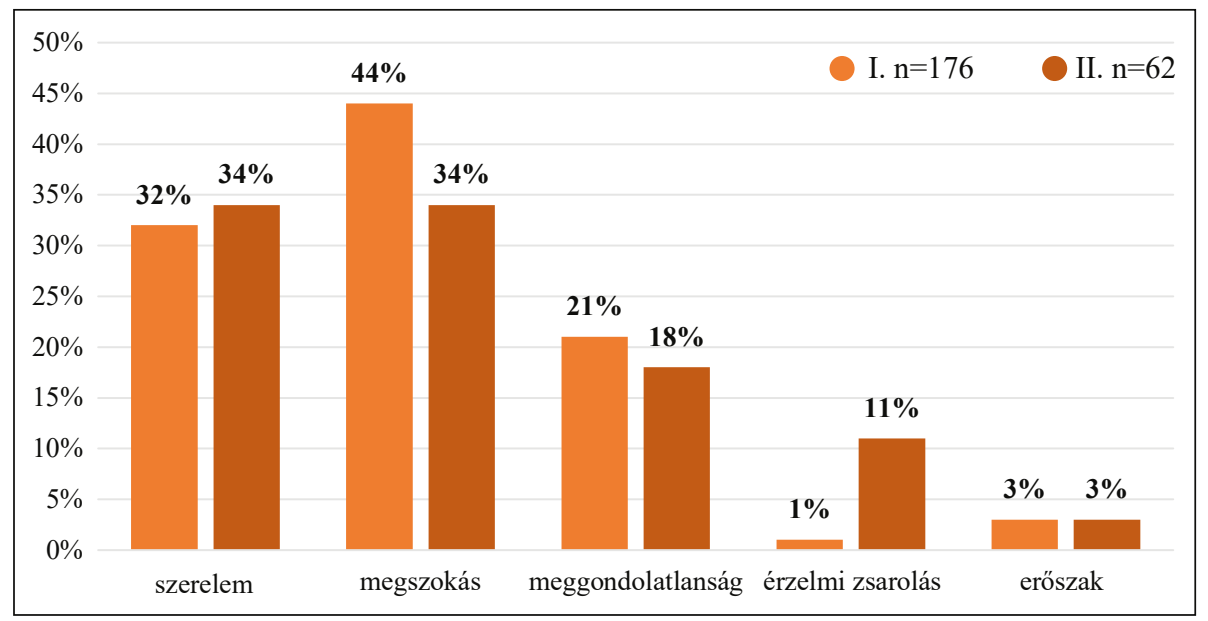

Forrás: A szerző saját szerkesztése.

Két fó a prostitúció sajátos módjára kényszerült (például az ivócimborák szexuális szolgáltatás fejében juttattak italt, vágtak fel tüzifát és hallgattak el bolti lopást).

5 A pszichiátria a diagnózist köztes eredménynek tekinti, munkahipotézisnek, a terápiás munkában orientáló segédeszköznek (Spazier, 1982), ezzel szemben áll az igazságügyi pszichiátria természete. Jóllehet az igazságügyi szakértőként is tevékenykedő pszichiáterek előzetes megállapításként, hipotézisként tekintenek saját diagnózisaikra, a diagnózisok önálló életre kelnek és az eljárás döntő szakaszaiban már bizonyítékként szerepelnek (Steller, 1988). A pszichiátriai szakértői munka így az ítélkezés egy helyzetévé vált (Wiesner, 1996). 
Ibolya 41 éves ( 2 gyermeke nevelőszülőknél), egyedül él egy valaha szebb napokat látott családi házban, áram, víz kikapcsolva, kívül-belül omlik, romlik, a kert gondozatlan, iszonyú szeméttömeg mindenütt. Alkoholista, munkanélküli, debilis(?), 8 osztályt végzett.

Ivócimbora: Ibolya még nálam is jobban bírja az italt. Szexuálisan többször voltam vele. Ma elmentem Ibolyához, belépek a leszakadt ajtón és már látom, hogy nincs nagy hasa. Hallottam bentről egy macskanyávogás-szerüt, kérdeztem macskád van? Ibolya mondta, hogy megszült, a szobában feküdt a gyerek csupaszon, Ibolya betekerte egy plédbe, és mondta, vigyem a kórházba, tegyem az inkubátorba. Nem volt már régen fütés a házban.

7. számú ábra: Fogamzásgátlás a foganáshoz vezető aktus során

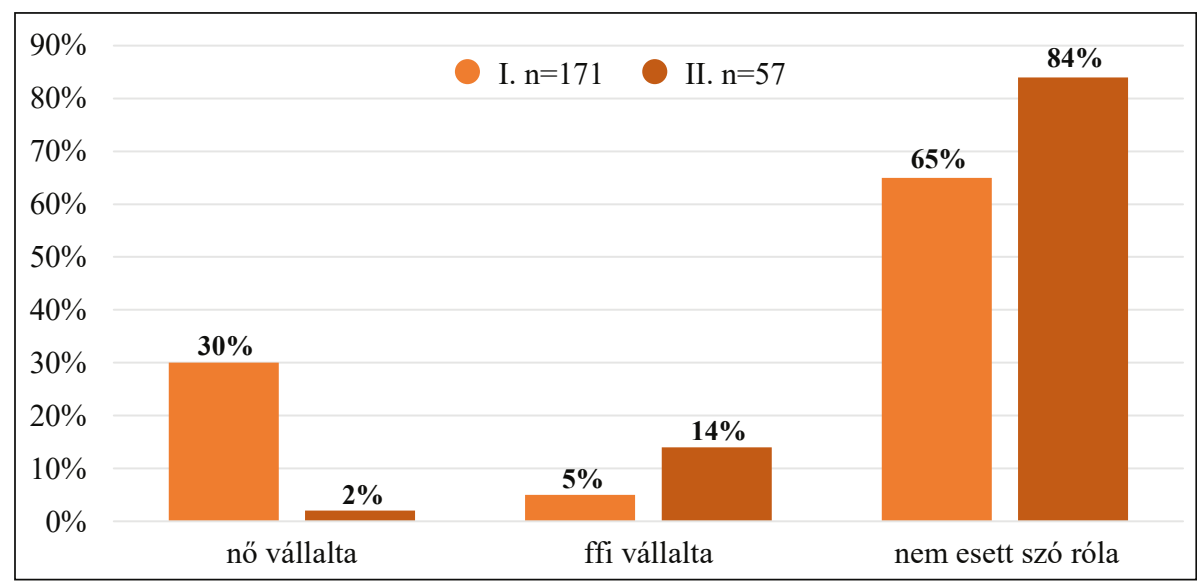

Forrás: A szerző saját szerkesztése.

A második kutatási időszak egyik legszomorúbb adata a fogamzásgátlás adott helyzetét mutatja (7. számú ábra), de egyéb adatok is arra utalnak, hogy a kommunikáció inkább általános szokásait látjuk. Az még érthető, hogy az erőszaktevő nem tárgyalja meg áldozatával a védekezés módját, az már viszont nem, hogy a szeretkező párok majd mindegyike - legyenek bármilyen természetü kapcsolatban - erről szót sem ejt, leszámítva a 4 udvarlót, 3 élettársat és 1 férjet, akik magukra vállalták a feladatot.

\section{Kik elött titok a titok?}

Tekintve, hogy az adatok a vallomásokból származnak, hitelességüket több szinten kezelem. A családtagok megtagadhatják a vallomástételt, itt tehát csak az 
erre hajlandókét látjuk. A társas környezet szereplői igazmondásra kötelezettek, a védőnő és az orvos többszörösen is. Az első szakaszban a terhességről tudás és sejtelem szoros együtt járást mutat, a két tudásminőség mintegy szinonimaként felfogását jelzi. Az elkövető szülei veszik észre leggyakrabban - föként hajadon - leányuk állapotát, de a korholás, fenyegetés és a környezet pletykaszintü gyanújának visszautasítása eszközein nem lépnek túl (apák nem foglalkoznak az ilyen női dolgokkal, az anyák is inkább a környezet előtt óvják a látszatot). A majd 11\%-ot kitevő biológiai apák jelentős hányadát a megmaradt udvarlók teszik ki (többségük az első gyanús jelre elillan), ők segítséget ígérnek a szülés megindulása idejére, egy pár a szabadságvesztés idején kötött házasságot. A néhány vallomástévő férj jellemző fordulata szerint: „Nyomozó úr, most Öntöl tudtam meg, hogy a feleségem terhes volt." A szomszéd óvakodik szóvá tenni a helyzetet, a barátnő ismeri és őrzi a titkot. A második szakaszban az apák 7\%-a tett vallomást, elfoglaltak, feleségük feladatának tekintik a leányok nevelését. Az anyák is elfoglaltak, közülük többen orvoshoz is vitték leányukat (nem feltétlenül szülész-nőgyógyász szakorvoshoz), gyanújukat (35\%) nem sikerül bizonyítani. A biológiai apák majd 25\%-a többnyire kortárs, sőt iskolatárs és együtt böngészik a netet a lehetséges kiutat keresve. A szomszédok majd 50\%-a sejti a terhességet, de nem akarnak belekeveredni egy kétes kimenetelủ személyiségi jogi huzavonába. Figyelemre érdemes azoknak az apáknak a nyilatkozata, akik azt állítják, hogy nem tudtak a terhességröl. Az idegenek, az egyszeri kalandorok és az erőszaktevők esetében ez hiteles, róluk adatunk sincs. Hiteles, ám számos egészégügyi-jogi problémát takar ez a helyzet. Elgondolkodtató viszont a terhesség hónapjait a hitvesi ágyban együtt töltő férjek valós vagy megjátszott tudatlansága. A második kutatási időszakban a nemi aktus pózának megváltoztatásáról esik szó gyakran a férj vallomásában. Kérdés, miért tesznek egyáltalán vallomást? Érdemes talán, mert így semmiféle joghátrány nem éri őket, a vallomástételre nem vállalkozók ezzel legalább egy kissé gyanússá teszik magukat a nyomozati szakban. Mindent egybevetve, a családi és a tágabb társas környezetben a szexualitás át nem hágható kommunikációs gátat emel, ez pedig a beszélgetést problémamegoldó módszerként amúgy is kevéssé alkalmazó közegben végzetes következménnyel jár (8. és 9. ábra). A titkolt terhesség történetének lehetséges sorsfordító szereplője a védőnő. ${ }^{6}$ A kutatás első szakaszában csak saját vezetőjükkel, felettesükkel oszthatják meg szakmai problémájukat, ezt gyakran meg is teszik, csekély eredménnyel. A második szakaszban már hatósági jogkörszerü

6 A helyi önkormányzatokról szóló 1990. évi LXV. törvény 97. §-ának b) pontjának és az egészségügyről szóló 1997. évi CLIV. törvény 247. §-a (2) f) pontjában foglalt felhatalmazás alapján született 49/2004 (V. 21.) EszCsM rendelet a területi védőnői ellátásról. 
jogosítvánnyal bővül a védőnők mozgástere, kötelesek (azaz a jogalkotó leveszi vállukról az árulkodás terhét) az önkormányzat szociális-gyermekvédelmi munkatársainak, súlyosabbnak ítélt esetben pedig a rendőrségnek jelzést adni. Annak ellenére, hogy ezzel veszélyeztetik a családdal kialakult bizalmi viszonyt, szükség esetén mégis megteszik, példáink a sikertelen ügymeneteket mutatják. Gyakran azonban eredményt érnek el, a sikerről értelemszerüen kevés adattal rendelkezünk, amivel igen, az a Bölcső Alapítvány gyakorlatából származik, a média után a második helyen állnak a megelözésben.

8. számú ábra: A környezet percepciója a terhességröl (I. kutatási szakasz)

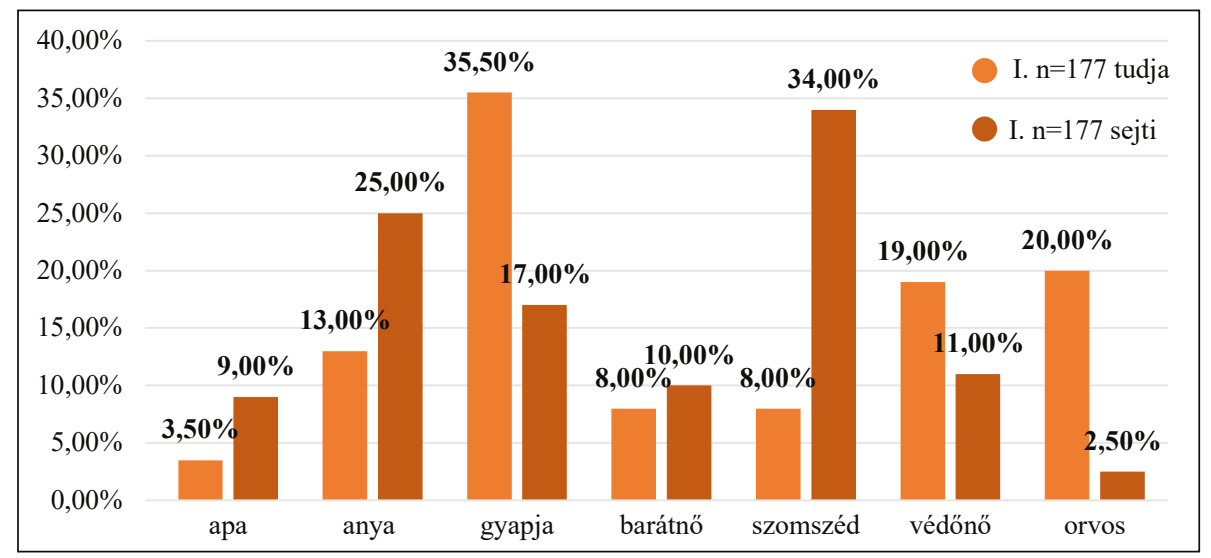

Forrás: A szerző saját szerkesztése.

9. számú ábra. A környezet percepciója a terhességröl (II. kutatási szakasz)

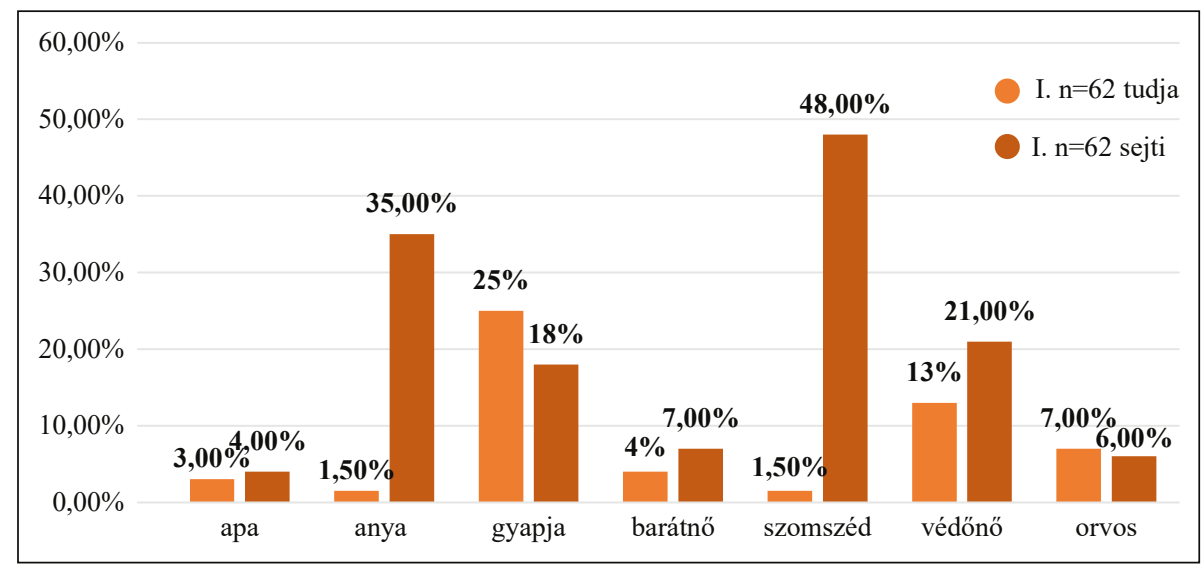

Forrás: A szerző saját szerkesztése. 


\section{Szülés, elkövetés}

Az elkövetők 91-93\%-os arányban problémamentesen hordják ki terhességüket. Természetesen nem tudunk azokról az esetekről, amelyekben a terhesség időszakában súlyos komplikációk léptek fel és ezek következtében a magzat kihordása, a szülés nem következett be. Amiről az ügyiratokból újra megbizonyosodtam, a titokkal veszélyeztetett várandós állapot két igen különös, a magzat együttmüködését is igénylő fiziológiai jelenségéről. Az alkati sajátosságok adatai, de a példaként összefoglalt esetek is arra utalnak, hogy a titkolt terhesség gyakran nem mutatja a szokásos külső jeleket, így a has domborodását sem. Ugyancsak különös, hogy azok a nők, akik korábbi terhességeiket megszenvedték, ezt a terhességüket problémamentesen hordják ki. Vannak még a szülési tapasztalattal rendelkező nők esetében is számosak, akik terhes állapotukról a magzat megmozdulásakor szereznek tudomást. Néhányan még ekkor sem, a szülés megindulását erős székelési ingerként azonosítják.

Bori 28 éves, falun él, udvarosként laknak a házban, 8 osztályt végzett, szakképzettség nincs, alkalmi munkás, férjezett, 2 gyerekük van, 7 és 3 évesek (a nagyobbik gyereket örökbe adták, a kicsi intézményben).

Bori: Éjjel 1-kor úgy éreztem nagyvécéznem kell, megkönnyebbültem, majd egyből elájultam. Ezután arra emlékszem, hogy a földön fekszem, és ott vannak a mentősök, ők mondták, hogy a kicsi született meg. Az első császárral jött, a másodikkal egy órán át kínlódtam. Most semmi nem volt.

Nőgyógyász: 15 hetesen jelentkezett, ez későinek számít, megvizsgáltuk, rendszertelenül jött, a terhesség problémamentes volt. Mindezt dokumentumok is igazolják.

Hasonló a helyzet a szülés folyamatával is, még azok az anyák is, akik korábban császármetszéssel hozták világra gyermeküket vagy farfekvéses szülést éltek át, ezt a szülést jelentős arányban észrevétlenül, egyedül bonyolítják le, különösebb utólagos komplikáció nélkül. (Zavartalan, gyors, olykor rohamos szüléssel hozza világra újszülöttjét az I. szakaszban az anyák 69\%-a, a II. szakaszban 59\%-uk.) Vannak azért, akik megszenvedik a szülést, súlyosan kivérzett, esetleg eszméletlen állapotban találnak rájuk és hívnak hozzájuk szakszerü segítséget. 
10. számú ábra: A szülés helyszine

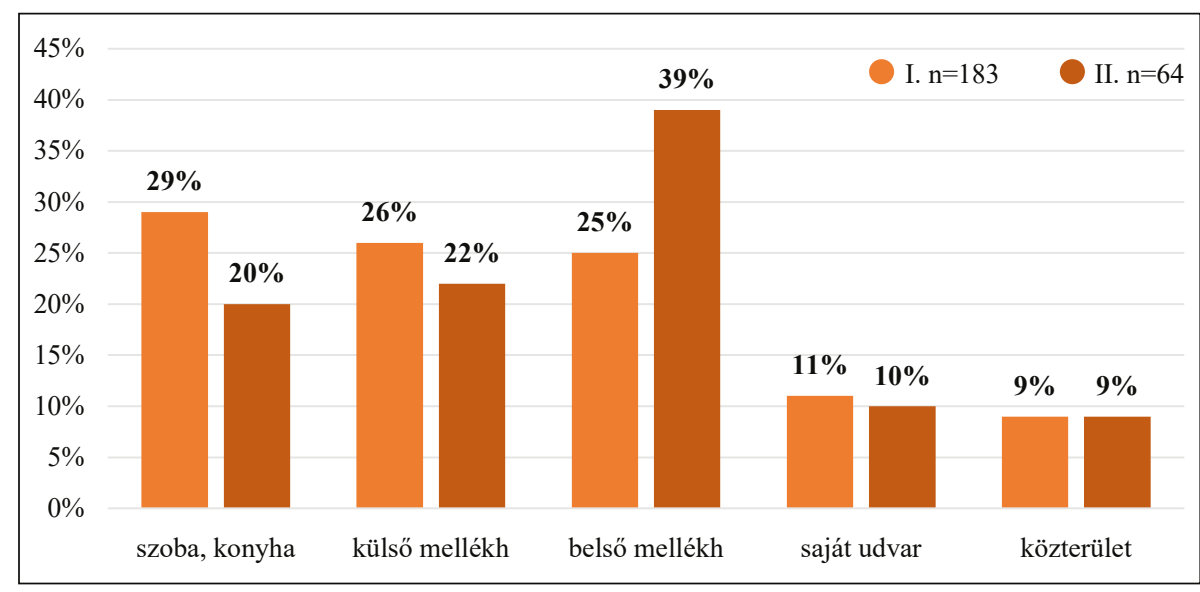

Forrás: A szerző saját szerkesztése.

A szülés színhelyét egyetlen szempont szerint választják a szülés megindulását követően, ebben is a titok fenntartásának kényszere vezeti őket. Mindkét kutatási időszakban azt állapítottuk meg, hogy olyan helyszínre igyekeznek, ahol a legkevésbé számíthatnak másokra, a családtagok felbukkanására (éppen nem használt szoba vagy külső mellékhelyiség, hátsó udvar), vagy ahol hosszas tartózkodásuk indokolható (belső mellékhelyiség). Csak ritkán kerül sor közterületen (például parkban, vasútállomás illemhelyén) lebonyolított szülésre (10. számú ábra).

11. számú ábra: $A$ szülés testhelyzete

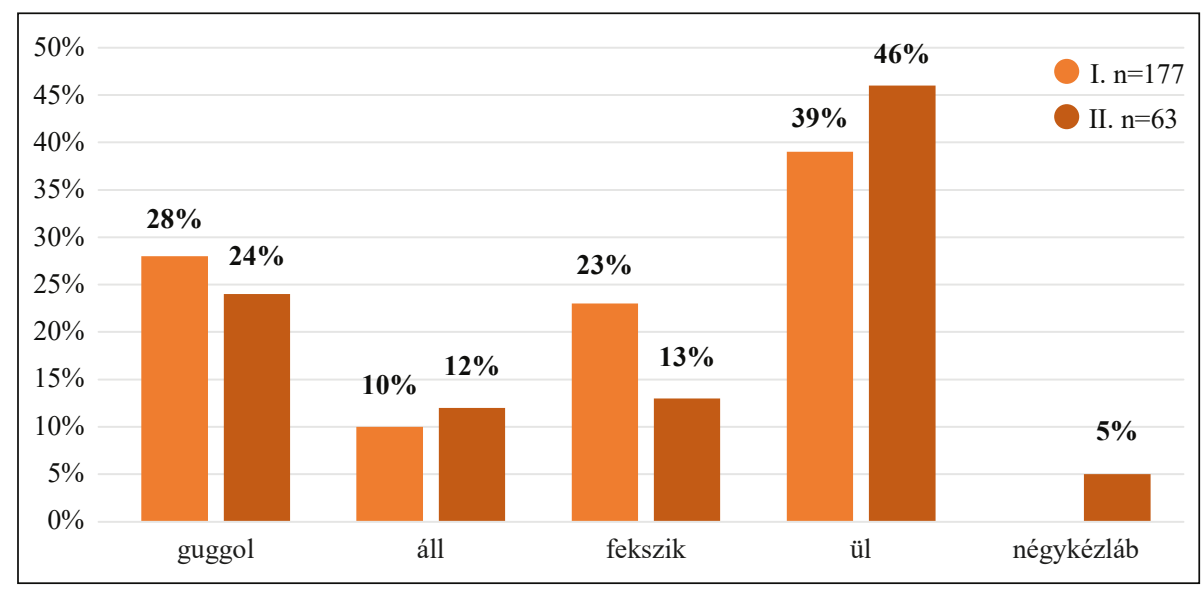

Forrás: A szerző saját szerkesztése. 
Tekintve, hogy a terhesség folyamata szakszerü támogatás mellőzésével zajlik, az anya rendszeresen téved a szülés várható időpontjának megjelölésében. Még a szülési tapasztalattal rendelkezők is, sőt az ő szükebb körükbe tartozók, azok, akik már nem is egy ízben hordtak ki titkolt terhességet, s csak a szülés megindulásának csalhatatlan jelei hatására kérték környezetük segítségét vagy maguk hívtak mentőt. Most ezzel elkéstek, egyikük mobiltelefonja éppen akkor merült le. Az első kutatási időszakban még nem terjedtek el az alternatív szülés különféle (a közeget és a pózt illető) lehetőségei, jóllehet ezek a történelemben sem ismeretlen megoldásmódok. Csupán azok az anyák szülnek fekve, akik oly mértékben érzik magukat rosszul, hogy csak ezt a módot képesek elviselni. Az újszülött már születése utolsó szakaszában is szenvedhet végzetes sérüléseket, ha például az anya állva szül és a méhlepényt a gyermek súlya húzza magával, ilyenkor a magzat jobb esetben füves, földes talajra esik, rossz esetben betonvagy kövezett felületre (11. számú ábra).

Szilvi 19 éves: Terpeszben álltam fél óráig, akkor jött ki a gyerek, koppant a padlón, belecsúsztam a kádba, nem tudom mennyi idő telt el. Amikor magamhoz tértem foltokban láttam, folyamatosan véreztem. Megint nyomnom kellett, valami lógott belőlem. A gyerek nem mozgott, nem lélegzett, nem sírt. Nem tudatosult bennem, hogy ez az én gyerekem, nem néztem utána az interneten, hogy mit kell csinálni egy gyerekkel. Lefeküdtem, felhívtam anyát, nagyon megijedt, azonnal jöttek. Danit is felhívtam, rögtön jött, ordítva szaladgált a ház körül, kinyitottam az ablakot, ott jött be. A szüleim 2 percre rá jöttek. Anyu bejött a szobámba, felállított, én mondtam neki, hogy nem akarok menni a pszichiátriára. Visszavitt a fürdőszobába, leültetett a kád lépcsőjére, egy törölközőben magamhoz szorítottam a babát, akkor tudatosult bennem, hogy egy gyermeket hoztam a világra, ami nem élt. Édesanyám kivette a kezemből a babát és mondta, mentőt kell hívni. Egyszer néztem utána egy szervezetnek itt a közelben, akik örökbefogadással foglalkoznak. Egy barátnőm van, vele eljárunk inni, vele sem beszéltem meg.

Gyakran merül fel a kérdés, hogy az anya vajon képes volt-e, képes lehetett-e a hagyományosan magányos szülés lebonyolítására, sőt az újszülött elrejtésére, felsírásának végzetes megakadályozására. Csak elvétve mutatkoznak jelek további személy jelenlétére, ők az első kutatási időszakban nem a szülésnél, hanem az utólagos cselekményben müködtek közre, a második szakaszban pedig egyetlen gyermek bántalmazó apja volt jelen, sajátos eszközökkel folytatta gyermeke anyjának bántalmazását, még a szülés közben is. A szülést közvetlenül követő mozzanatokat a titokhelyzet minden áron fenntartására törekvés vezeti, az újszülöttet a kézügybe eső textiliába bugyolálják, pólóba, törölközőbe, rongyokba. Majd így szekrénybe, dobozba vagy máshová rejtik. Az árnyékszéken 
szülök ${ }^{7}$ egy ütemben valósítják meg a szülés-ölés-rejtés lépéseit, és ez a megoldás még a második kutatási időszakban is előfordult jelentős elemszámmal.

12. számú ábra: $A z$ elkövetés módja

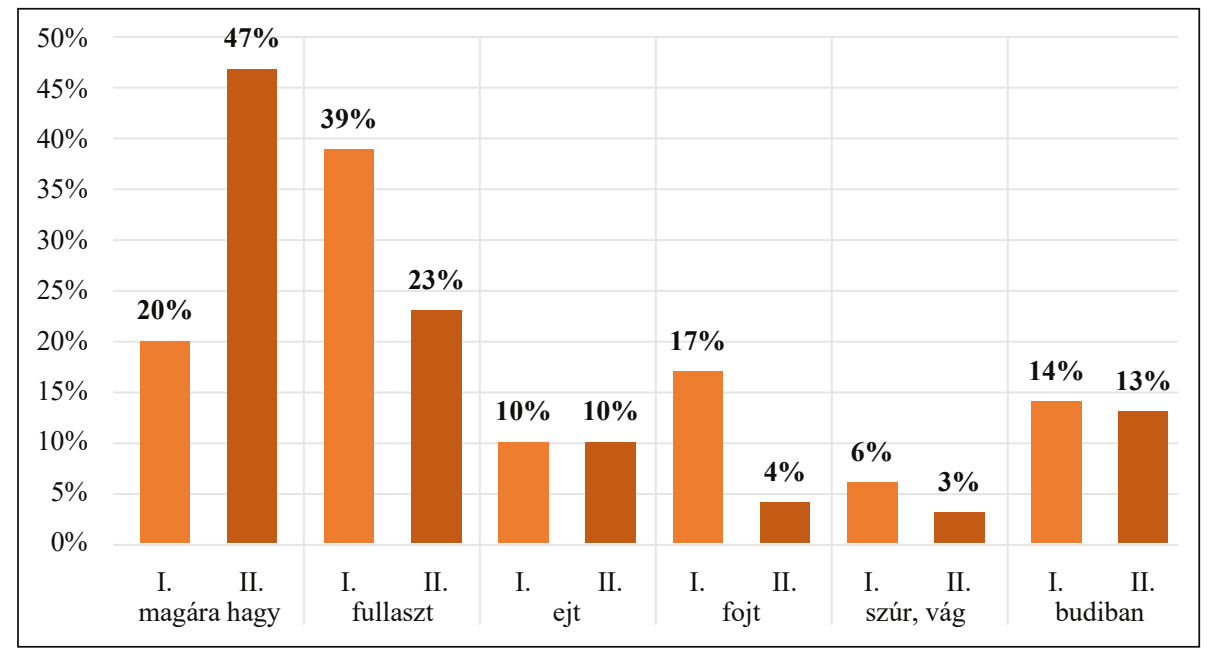

Forrás: A szerző saját szerkesztése.

Amint ez az iratanyagokból kiolvasható, a 12. számú ábrán pedig látható, az újszülöttek halálát nem az előkészületet is megtervező gyilkos szándék, hanem a titokhelyzet még mindig ható fenntartási kényszere, a kimerült pánikállapotból vagy éppen eszméletvesztésből következő passzív elkövetési módok idézik elö. A tevőleges ölés, a fojtás és szúrás az I. szakaszban 23\%-ot, a II. szakaszban pedig 7\%-ot tesz ki.

7 Egy, a 16. századból származó idézet szerint „Az árnyékszékek visszhangozzák az oda vetett gyermekek sikolyát" (Johansen, 1980). 
13. számú ábra: A rejtés módja

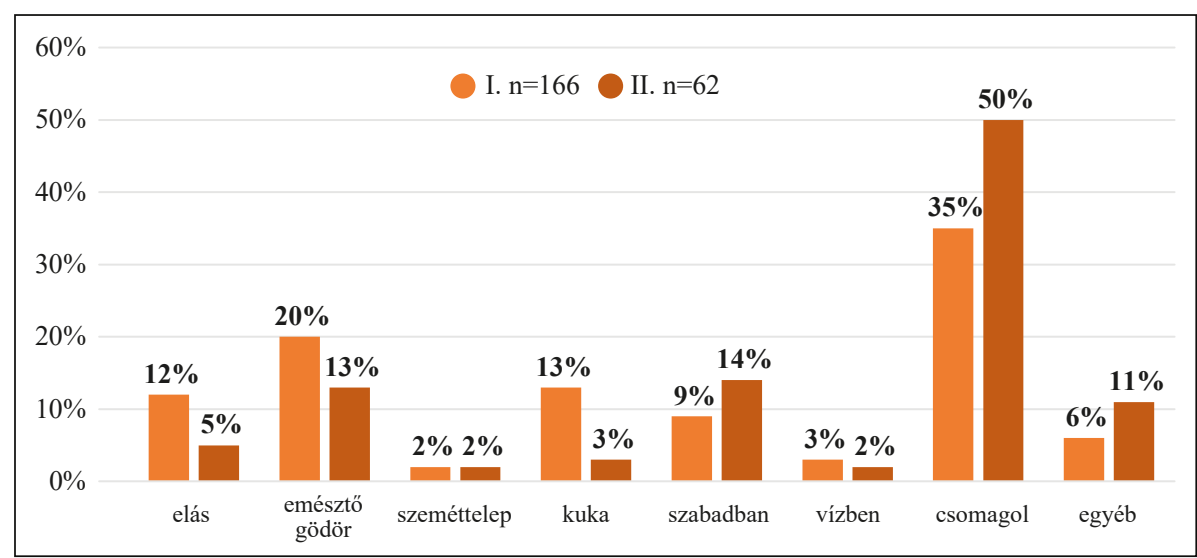

Forrás: A szerző saját szerkesztése.

A még élő vagy a meghalt újszülött elrejtését is a titokkényszer vezeti, a szülő nő állapotától függően választja, változtatja meg a rejtekhelyet. Az eszméletét elvesztő erre nem is képes. Aki csak rosszul van, vérzik becsomagolja az első keze ügyébe eső textildarabba az újszülöttet. A családi házban lakó anya becsomagolt újszülöttjét elássa a hátsó udvarban, az emeletes házban lakó pedig leviszi a kukába. Legtöbben azonban a becsomagolt újszülöttet a szülés-elkövetés közös színhelyén rejtik el (például szekrényben) (13. számú ábra).

14. számú ábra: A rendörségen bejelentést tevő személye

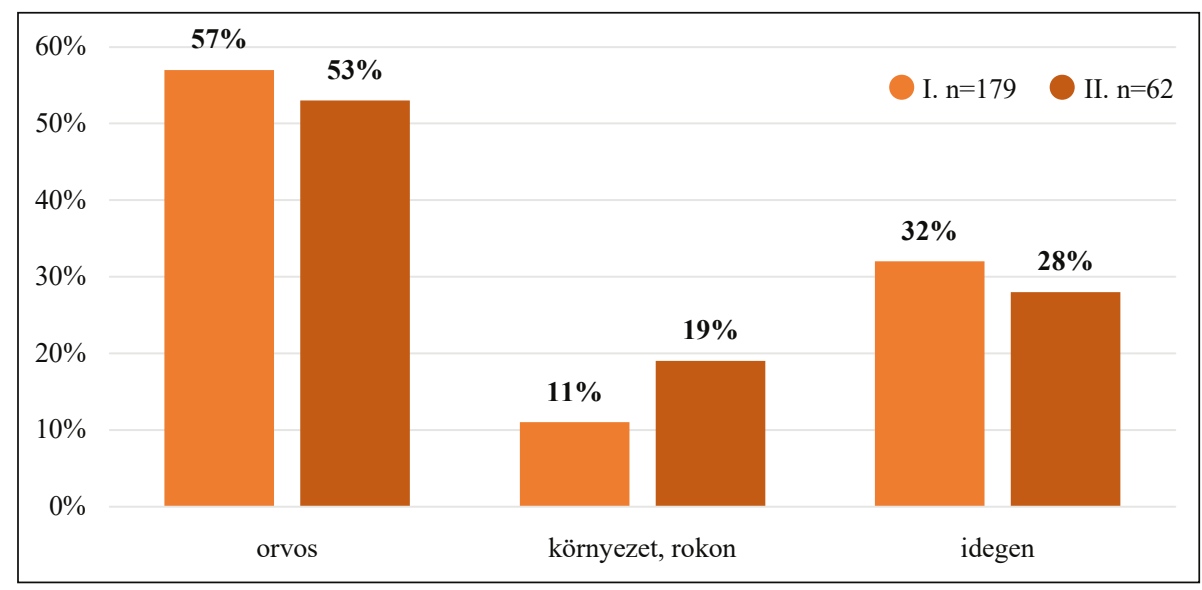

Forrás: A szerző saját szerkesztése. 
Legtöbbször a szülő nőt és/vagy az újszülöttet vizsgáló orvos tesz bejelentést, mert erre kötelezett. Az orvost viszont többnyire a közvetlen környezet, néha pedig maga a szülő nő értesíti, hívja. A családtagok, a munkatársak csak akkor tesznek közvetlenül rendőrségi bejelentést, ha nyilvánvaló az újszülött halála. Az idegenek által tett bejelentések között fordult elő gyakrabban, hogy kedvező együtt állás mellett (enyhe idő, a szülést követően eltelt idő rövidsége) az újszülöttet még életben találták, megmenthető volt (14. számú ábra).

\section{Következtetések, kitekintés}

Az adatok bemutatásából származó megállapítások korunkra is érvényesen igazolják a felvilágosodás filozófusai, jogászai, pedagógusai által egybehangzóan hirdetett tételt, mely szerint az újszülöttölés az adott társadalmat, kort jellemzi, ennél fogva kulcsbüntettnek tekinthető. ${ }^{8} \mathrm{~A}$ kulcsbüntett büntetéstörténetére visszatekintve jól látható, hogy a kor, a társadalom miként szemléli a család, benne vagy azon kívül a nő és a gyermek értékét. ${ }^{9}$ A kulcsbüntett vizsgálata éppen ezért arra kötelez, hogy az adott korban, társadalomban a megelőzés további, elsődleges és másodlagos lehetőségeit keressük, máig érvényesnek tekintve Beccaria gondolatát arról, hogy amíg nem tettünk meg minden tôlünk telhetôt az új életek megmentésére, addig nem igazságos a végletesen-végzetesen szorult helyzetbe került anya elítélése (Beccaria, 1887). Jelen első közlemény a két kutatási időszak alapvetőnek ítélt adatainak bemutatására szorítkozik, a lényegesebb változások pontjaira utalásokkal. További, már mélyebb elemzések feladata lesz megvilágítani a cselekményhez vezető út egyes lényeges sajátságait, a titokkényszer összetevőinek változását, az együtt élők kommunikációs szokásait. Ezzel mintegy összefüggésben elemzést érdemel az újszülöttölést elkövetett nők nemi kompetenciája, ezzel is hozzájárulásként a szexuális nevelés minden szocializációs színtéren nehéz feladatának teljesítéséhez. Külön tanulmányban elemezzük a megelőzés lehetőségeit, amelynek tárgya a megelőzés müködő lehetőségeinek elemzése lesz, különös tekintettel a védőnők és az erre a célra szerveződött civil szervezetek (Bölcső Alapítvány) tevékenységére.

8 Ekkor (ti. a felvilágosodás korában) azonban ez a kérdés már Európa-szerte nem csak kriminalistákat, de költőket és bölcseket foglalkoztatott, $\mathrm{s}$ ez volt az a kulcsbüntett, mely jelképes problémává is vált (Raskó, 1978).

9 Pestalozzi bátor műve, a „Törvényhozás és gyermekölés” 1783-ban utal az anya által elkövetett gyermekölés elterjedt jelenségére. Ezt a kérdést már 1780-ban megírt pályamüvében is felveti. 


\section{Felhasznált irodalom}

Beccaria C. (1887). Büntett és büntetés. Révai Kiadó.

Cseres J. (1996a). A titok. Adalékok az újszülöttgyilkosságok előzményeihez. Társadalmi Szemle, 54(6), 48-60.

Cseres J. (1996b). A véletlen. Adalékok az újszülöttek sérelmére elkövetett emberölések latenciájának megítéléséhez. Belügyi Szemle, 43(9), 13-26.

Cseres J. (2000). Eltékozolt újszülöttek. BM Kiadó

Johansen, E. M. (1978). Betrogene Kinder. Kultgut.

Pestalozzi, H. (1783). Über Gesetzgebung und Kindermord. Auf Kosten des Berfassers, und in Kommißion den der Buchhandlung der Belehrten.

Peters, K. (1988). Strafrechtspflege und Menschlichkeit. Festschrift.

Raskó G. (1978). Női bünözés. Közgazdasági és Jogi Könyvkiadó.

Solt Á. (2020). Az újszülöttek sérelmére elkövetett emberölések jellemzői és az elmúlt évtizedek tendenciája. Kriminológiai Tanulmányok, 57, 84-104.

Spazier, D. (1966). Der Tod des Psychiaters. Syndikat.

Steller, M. (1988). Standards der forensisch-psychologischen Begutachtung. Monatsschrift für Kriminologie und Strafrechtsreform, 71, 16-27.

Wiesner, A. (1996). Mütter, die töten. Psychoanalytische Erkenntnis und forensische Wahrheit. W. Fink Verlag.

\section{Alkalmazott jogszabályok}

1990. évi LXV. törvény a helyi önkormányzatokról

1997. évi CLIV. törvény az egészségügyről

49/2004 (V. 21.) EszCsM rendelet a területi védőnői ellátásról

\section{A cikk APA szabály szerinti hivatkozása}

Cseres J. (2021). Eltékozolt újszülöttek 2. Belügyi Szemle, 69(SI3), 9-31. https://doi.org/10.38146/ BSZ.SPEC.2021.3.1 